\title{
Yield, Yield Components, Soil Chemical Properties, Plant Physiology, and Phosphorus Use Efficiency in Soybean Genotypes
}

\author{
A. Moreira, L. A. C Moraes \& L. G. Moretti
}

To cite this article: A. Moreira, L. A. C Moraes \& L. G. Moretti (2017) Yield, Yield Components, Soil Chemical Properties, Plant Physiology, and Phosphorus Use Efficiency in Soybean Genotypes, Communications in Soil Science and Plant Analysis, 48:20, 2464-2476, DOI: 10.1080/00103624.2017.1416126

To link to this article: https://doi.org/10.1080/00103624.2017.1416126

\section{曲 Published online: 15 Dec 2017.}

Submit your article to this journal

Џll Article views: 60

View Crossmark data ¿ 


\title{
Yield, Yield Components, Soil Chemical Properties, Plant Physiology, and Phosphorus Use Efficiency in Soybean Genotypes
}

\author{
A. Moreira ${ }^{a}$, L. A. C Moraes ${ }^{a}$, and L. G. Moretti ${ }^{b}$ \\ aDepartment of Plant Nutrition, National Soybean Research Center of EMBRAPA, Londrina, Paraná State, Brazil; \\ ${ }^{b}$ Department of Crop Science, São Paulo State University, Campus of Botucatu, São Paulo State, Brazil
}

\begin{abstract}
Expansion of soybean [Glycine max (L.) Merrill] cultivated in Brazil to regions with low fertility soils gave rise to studies on the possibility of obtaining highly productive cultivars with high nutrient use efficiency. An experiment in greenhouse conditions was conducted to assess phosphorus (P) use efficiency (PUE) by 13 soybean genotypes. The genotypes were grown in an Ustoxix Quartzipsamment with two $P$ rates $\left[0\right.$ (no $P$ application) and $150 \mathrm{mg} \mathrm{P} \mathrm{kg}^{-1}$ ], whose source was monoammonium phosphate (MAP, $\mathrm{P}_{2} \mathrm{O}_{5} 44 \%$ ). Shoot dry weight $(\mathrm{SDW})$, grain yield $(\mathrm{GY})$, grain harvest index $(\mathrm{GHI})$, relative yield (RY), and physiological components (photosynthetic rate, stomatal conductance, respiratory rate, and internal $\mathrm{CO}_{2}$ concentration) were influenced by soybean genotypes and $\mathrm{P}$ rates. Genotypes BMX Apolo RR, BRS 360RR, BRS 378RR, CD 219RR, DM 2302RR, TMG 7161RR, and Vtop RR were classified as non-efficient and non-responsive to $P$ application, while BMX Potência RR, Vmax RR, FPS Solar RR, NA 5909RR, TMG 1066RR, and M 6210 IPRO were classified as efficient and responsive. Phosphorus application increased the values of physiological components, which was not observed for $\mathrm{N}, \mathrm{K}, \mathrm{Ca}, \mathrm{Mg}$, and $\mathrm{S}$ concentration in the leaves and grains. Soybean genotypes selection for increased $P$ efficiency could help growers overcome the problem of soybean cultivation on new areas or degraded pastures.
\end{abstract}

\section{ARTICLE HISTORY}

Received 24 September 2016 Accepted 7 December 2017

\section{KEYWORDS}

Glycine max; nutritional status; soil fertility; yield components

\section{Introduction}

Brazilian agriculture depends on relatively high fertilizers rates to ensure economic feasibility of planting and replacement of nutrients in areas cultivated with soybean and particularly for the expansion of soybean crops to less fertile areas and degraded pastures (Goedert and Sousa 1986; Lápido-Loureiro, Melamed, and Figueiredo Neto 2009). In particular, phosphorus (P) deficiency in these soils has had a significant impact on yield (Chien and Menon 1995; Fageria et al. 2013).

The use of species and/or cultivars with high capacity to absorb $\mathrm{P}$ in conditions of low $\mathrm{P}$ supply in the soil, or lower need of the nutrient for optimal growth has been described as the best strategy for cultivation in these areas (McIvor 1984; Silva and Faria 1989). The high cost of fertilizers and the possible shortage of the nutrient in the future, especially $\mathrm{P}$, is another obstacle, since higher exploration expenses and depletion of global reserves may restrain their use (Batten 1992; Cordell, Drangert, and White 2009).

The P-use fertilizers increase distribution and translocation, with increase in grain yield and greater nutrients' accumulation in dry weight (Xie, Niu, and Niu 2016). Phosphorus use efficiency by

CONTACT A. Moreira adonismoreira66@gmail.com @ Department of Plant Nutrition, National Soybean Research Center of EMBRAPA, Londrina, Paraná State, Brazil. 
plants in response to low $\mathrm{P}$ concentration in soil has been associated to increased root system volume, with larger amounts of root absorbent hairs, high $\mathrm{P}$ uptake rates per unit root weight, increased $\mathrm{P}$ translocation to terminal branches, low growth rates, and high $\mathrm{P}$ use efficiency (Fageria and Moreira 2010; Gonçalves and Lynch 2014; Silva and Faria 1989). Nutritional efficiency involves an agronomic aspect due to the efficiency of a genotype to generate good yields even in soils with low P levels, and a physiological aspect, whose nutritional efficiency concerns the efficiency of a genotype to absorb soil nutrient, distribute it, and use it internally (Fageria 2009; Furtini Neto et al. 1996).

Based on these observations, the present study aimed to assess 13 soybean genotypes regarding $P$ use efficiency, through assessment of yield components (SDW, GY, NPP, GHI, and RY), nutritional status, physiological components, and soil chemical properties of an Ustoxix Quartzipsamment.

\section{Material and methods}

\section{Site and soil characteristics}

The experiment was conducted in greenhouse conditions at Embrapa Soja, Londrina County, Paraná State, Brazil $\left(23^{\circ} 11^{\prime} 39^{\prime \prime}\right.$ LS and $51^{\circ} 10^{\prime} 40^{\prime \prime}$ LW) to assess P use efficiency by 13 soybean genotypes. The soil used was an Ustoxix Quartzipsamment, of sandy texture $\left(142 \mathrm{~g} \mathrm{~kg}^{-1}\right.$ of clay and $841 \mathrm{~g} \mathrm{~kg}^{-1}$ of sand), collected from 0 to $20 \mathrm{~cm}$ depth in the Luís Eduardo Magalhães County, Bahia State $\left(20^{\circ} 45^{\prime} 04^{\prime \prime}\right.$ LS and $51^{\circ} 40^{\prime} 42^{\prime \prime}$ LW), with the following chemical properties (Embrapa 1997) before the treatments application: $\mathrm{pH}\left(\mathrm{H}_{2} \mathrm{O}\right)=3.9$, organic matter $(\mathrm{OM})=9.3 \mathrm{~g} \mathrm{~kg}^{-1}$, available $\mathrm{P}=1,0 \mathrm{mg} \mathrm{kg}{ }^{-1}$, exchangeable potassium $\left(\mathrm{K}^{+}\right)=0.02 \mathrm{cmol}_{\mathrm{c}} \mathrm{kg}^{-1}$, exchangeable calcium $\left(\mathrm{Ca}^{2+}\right)=0.07 \mathrm{cmol}_{\mathrm{c}} \mathrm{kg}^{-1}$, exchangeable magnesium $\left(\mathrm{Mg}^{2+}\right)=0.05 \mathrm{cmol}_{\mathrm{c}} \mathrm{kg}^{-1}$, exchangeable aluminum $\left(\mathrm{Al}^{3+}\right)\left(\mathrm{KCl} 1.0 \mathrm{~mol} \mathrm{~L} \mathrm{~L}^{-1}\right)=0.7 \mathrm{cmol}_{\mathrm{c}} \mathrm{kg}^{-1}$, potential acidity [hydrogen $\left(\mathrm{H}^{+}\right)$ $\left.+\mathrm{Al}^{3+}\right]=3.4 \mathrm{cmol}_{\mathrm{c}} \mathrm{kg}^{-1}$, sulfur $\left(\mathrm{S}_{-}-\mathrm{SO}_{4}{ }^{2-}\right)=5.8 \mathrm{mg} \mathrm{kg}{ }^{-1}$, cation exchange capacity [CEC $\left(\sum \mathrm{K}^{+}\right.$, $\left.\left.\mathrm{Ca}^{2+}, \mathrm{Mg}^{2+}, \mathrm{H}^{+}+\mathrm{Al}^{3+}\right)\right]=3.5 \mathrm{cmol}_{\mathrm{c}} \mathrm{kg}^{-1}$, effective $\mathrm{CEC}=\left[\left(\sum \mathrm{K}^{+}, \mathrm{Ca}^{2+}, \mathrm{Mg}^{2+}, \mathrm{Al}^{3+}\right)\right]=0.84 \mathrm{cmol}_{\mathrm{c}}$ $\mathrm{kg}^{-1}$, base saturation $-\mathrm{V}\left[\left(\sum \mathrm{K}^{+}, \mathrm{Ca}^{2+}, \mathrm{Mg}^{2+} / \mathrm{CEC}\right) \times 100\right]=4.1 \%$, available boron $(\mathrm{B})=0.13 \mathrm{mg}$ $\mathrm{kg}^{-1}$, available copper $(\mathrm{Cu})=0.1 \mathrm{mg} \mathrm{kg}^{-1}$, available iron $(\mathrm{Fe})=59.0 \mathrm{mg} \mathrm{kg}^{-1}$, available manganese $(\mathrm{Mn})=0.3 \mathrm{mg} \mathrm{kg}^{-1}$, and available zinc $(\mathrm{Zn})=0.2 \mathrm{mg} \mathrm{kg}^{-1}$.

Available $\mathrm{P}$, copper $(\mathrm{Cu})$, iron $(\mathrm{Fe})$, manganese $(\mathrm{Mn})$, zinc $(\mathrm{Zn})$, and exchangeable $\mathrm{K}$ were extracted by Mehlich $1[0.05 \mathrm{M}$ of hydrochloric acid $(\mathrm{HCl})+0.0125 \mathrm{M}$ of sulfuric acid $\left(\mathrm{H}_{2} \mathrm{SO}_{4}\right)$ ]. Phosphorus was colorimetrically determined, $\mathrm{K}$ concentration was determined by flame photometry, and $\mathrm{Cu}, \mathrm{Fe}, \mathrm{Mn}$, and $\mathrm{Zn}$ concentration by atomic absorption spectrometry. Exchangeable $\mathrm{Ca}^{2+}, \mathrm{Mg}^{2+}$, and $\mathrm{Al}^{3+}$ were extracted with potassium chloride $(\mathrm{KCl}) 1.0 \mathrm{~mol} \mathrm{~L}^{-1}$. Exchangeable $\mathrm{Al}^{3+}$ was titrated with sodium hydroxide $(\mathrm{NaOH})$ and exchangeable $\mathrm{Ca}^{2+}$ and $\mathrm{Mg}^{2+}$ by atomic absorption spectrometry. Potential acidity was determined by SMP solution (Shoemaker, Mclean, and Pratt), available $\mathrm{B}$ by hot water, $\mathrm{S}-\mathrm{SO}_{4}{ }^{2-}$ by $\mathrm{Ca}\left(\mathrm{H}_{2} \mathrm{PO}_{4}\right)_{2}$, organic matter $(\mathrm{C} \times 1.724)$ using Walkley-Black and clay and sand concentrations were measured using the pipette method, according to methodology described in the soil analysis manual of Embrapa (1997).

\section{Statistical design, fertilization, and planting}

The experimental design was a split plot with two $\mathrm{P}$ rates in the main plots and 13 genotypes in the subplots. The genotypes tested were BMX Apolo RR, BMX Potência RR, BRS 360RR, BRS 378RR, CD 219RR, DM 2302RR, M 6210 IPRO, NA 6262RR, FPS Solar IPRO, TMG 1066RR, TMG 7161RR, Vmax RR, and Vtop RR and two $\mathrm{P}$ rates, low $\left(0 \mathrm{mg} \mathrm{kg}^{-1}\right.$ of $\mathrm{P}$-natural level of the soil) and high (150 $\mathrm{mg} \mathrm{kg}^{-1}$ of $\mathrm{P}$ ), applied as monoammonium phosphate (MAP$44 \%$ of $\mathrm{P}_{2} \mathrm{O}_{5}$ ). Thirty days before planting, soil base saturation $(\mathrm{V})$ was raised to $70 \%$ with the 
incorporation of dolomitic lime [calciulm oxide $(\mathrm{CaO}) 27.8 \%$, magnesium oxide $(\mathrm{MgO}) 19.6 \%$, and neutralizing power of calcium carcarbonate $\left(\mathrm{CaCO}_{3}\right)$ of $\left.85.5 \%\right]$.

The experiment was conducted in clay pots with $3.0 \mathrm{dm}^{3}$ of soil passed through $2.0 \mathrm{~mm}$ sieve were used. Except for N, which was supplied by inoculation of seeds with Bradyrhyzobium elkanii (SEMIA 5019) + B. japonicum (SEMIA 5079), fertilization with K, S, B, colbalt (Co), Cu, Fe, Mn, molybdenum (Mo), nickel (Ni), and Zn were conducted according to Moreira and Fageria (2010) adapted from Allen, Terman, and Clements (1976) for experiments in greenhouse conditions [150 mg kg ${ }^{-1}$ of MAP, $50 \mathrm{mg} \mathrm{Ca} \mathrm{kg}{ }^{-1}\left(\mathrm{CaSO}_{4}\right), 0.5 \mathrm{mg} \mathrm{B} \mathrm{kg}{ }^{-1}\left(\mathrm{H}_{3} \mathrm{BO}_{3}\right), 1.5 \mathrm{mg} \mathrm{Cu} \mathrm{kg}$ $\left(\mathrm{CuSO}_{4} \times 7 \mathrm{H}_{2} \mathrm{O}\right), 0.1 \mathrm{mg} \mathrm{Mo} \mathrm{kg}-1\left(\mathrm{Na}_{2} \mathrm{Mo}_{4} \times 2 \mathrm{H}_{2} \mathrm{O}\right), 2.5 \mathrm{mg} \mathrm{Fe} \mathrm{kg}{ }^{-1}\left(\mathrm{FeSO}_{4} \times 2 \mathrm{H}_{2} \mathrm{O}\right), 0.01 \mathrm{mg}$ $\mathrm{Co} \mathrm{kg}^{-1}\left(\mathrm{CoCl}_{2}\right), 0.01 \mathrm{mg} \mathrm{Ni} \mathrm{kg}{ }^{-1}\left(\mathrm{NiSO}_{4} \times 6 \mathrm{H}_{2} \mathrm{O}\right), 5.0 \mathrm{mg} \mathrm{Mn} \mathrm{kg}{ }^{-1}\left(\mathrm{MnSO}_{4} \times 3 \mathrm{H}_{2} \mathrm{O}\right)$ and $5.0 \mathrm{mg}$ $\mathrm{Zn} \mathrm{kg}^{-1}\left(\mathrm{ZnSO}_{4} \times 7 \mathrm{H}_{2} \mathrm{O}\right)$ ]. During V2 and V4 growth stages (Fehr et al. 1971), top-dressing fertilizations were made twice with $50 \mathrm{mg} \mathrm{K} \mathrm{kg}^{-1}\left(\mathrm{~K}_{2} \mathrm{SO}_{4}\right)$, totaling $100 \mathrm{mg} \mathrm{K} \mathrm{kg}^{-1}$ in the cycle. Two plans were maintained in each pot after germination, and soil moisture was maintained around $70 \%$ of total pore volume (TPV).

\section{Harvest and laboratory analyzes}

At the R2 reproductive stage (Fehr et al. 1971), in the morning, the following measurements were made from the third-fourth leaf pair from the apex: photosynthetic rate, $A\left(\mu \mathrm{mol} \mathrm{CO}_{2} \mathrm{~m}^{-2} \mathrm{~s}^{-1}\right)$, stomatal conductance, $g_{s}\left(\mathrm{~mol} \mathrm{H} \mathrm{H}_{2} \mathrm{O} \mathrm{M} \mathrm{s}^{-1}\right)$, transpiration, Trmmol $\left(\mathrm{mmol} \mathrm{H}_{2} \mathrm{O} \mathrm{m}^{-2} \mathrm{~s}^{-1}\right)$, and intercellular carbon dioxide concentration, $\mathrm{Ci}\left(\mu \mathrm{mol} \mathrm{CO}_{2} \mathrm{~mol}^{-1}\right.$ ) with photosynthesis meter (LI6400XT LICOR ${ }^{\oplus}$ ). Chlorophyll content was measured in same trifoliates with a SPAD unit (Chlrophyll Meter SPAD-502) and converted into chlorophyll $\left(\mathrm{mg} \mathrm{cm}^{-2}\right)$ using the equation $\hat{y}=16.033+(7.5774 \times$ SPAD $)$ proposed by Fritschi and Ray $(2007)$.

Senescent leaves were collected during the growth stage for measurement of shoot dry weight yield (SDWY) of the plant after drying at $65 \pm 2{ }^{\circ} \mathrm{C}$ until constant weight. After the physiological maturation (R8) stage, grain yield (GY) and number of pods per pot (NPP) were quantified. Samples of $0.1 \mathrm{~g}$ of leaflets and grains were digested in 2:1 nitric acid $\left(\mathrm{HNO}_{3}\right)$ and perchloric acid $\left(\mathrm{HClO}_{4}\right)$ for determination of the total $\mathrm{N}, \mathrm{P}, \mathrm{K}, \mathrm{Ca}, \mathrm{Mg}$, and $\mathrm{S}$ concentrations (Malavolta, Vitti, and Oliveira 1997). After the harvest, soil samples were collected from each pot for $\mathrm{pH}, \mathrm{MO}, \mathrm{P}, \mathrm{K}^{+}$, $\mathrm{Ca}^{2+}, \mathrm{Mg}^{2+}, \mathrm{H}^{+}+\mathrm{Al}^{3+}, \mathrm{Al}^{3+}, \mathrm{S}-\mathrm{SO}_{4}{ }^{2-}, \mathrm{B}, \mathrm{Cu}, \mathrm{Fe}, \mathrm{Mn}$, and $\mathrm{Zn}$ determination, according to methodologies described at Embrapa (1997). Relative yield (RY), grain harvest index (GHI), and P use efficiency (PUE) were calculated using the equations described by Fageria, Barbosa Filho, and Moreira (2008):

$\mathrm{RY}(\%)=\left(W / W_{1}\right) \times 100 ; W$ is GY at treatment $0 \mathrm{mg} \mathrm{P} \mathrm{kg}^{-1}$ (low) of each cultivar and $W_{1}$ is GY in treatment $150 \mathrm{mg} \mathrm{P} \mathrm{kg}^{-1}$ (high) for each cultivar.

$\mathrm{GHI}=[\mathrm{PG} /(\mathrm{GY}+\mathrm{SDW})] ; \mathrm{GY}$ and SDW of each genotype cultivar for each $\mathrm{P}$ rate $(0$ and $\left.150 \mathrm{mg} \mathrm{kg}^{-1}\right)$

$\mathrm{PUE}=\left(\mathrm{GP}\right.$ in $\mathrm{g}$ at $150 \mathrm{mg} \mathrm{P} \mathrm{kg}^{-1}-\mathrm{GY}$ in $\mathrm{g}$ at $\left.0 \mathrm{mg} \mathrm{P} \mathrm{kg}^{-1}\right) /($ leaf $\mathrm{P}$ concentration in $\mathrm{g}$ at $150 \mathrm{mg} \mathrm{P}$ $\mathrm{kg}^{-1} /$ leaf $\mathrm{P}$ concentration at $0 \mathrm{mg} \mathrm{P} \mathrm{kg}^{-1}$ )

\section{Statistical analysis}

The results of soil chemical properties, yield components, physiological components, and nutritional status were subjected to normality tests and later to analysis of variance (ANOVA), F test and means comparated by Scott-Knott test (Scott and Knott 1974) of means grouping at the 5\% probability level. 


\section{Results and discussion}

\section{Grain yield and yield components}

SDW yield and GY and GHI showed a significant genotype $\times$ P rates interaction (Table 1). At low $\mathrm{P}$ level, SDW ranged from $26.4 \mathrm{~g} /$ pot (TMG 7161RR) to $50.7 \mathrm{~g} /$ pot (FPS Solar IPRO), with an average value of $39.7 \mathrm{~g} /$ pot, while at high P level, SDW ranged from $42.1 \mathrm{~g} /$ pot (TMG 7161RR) to $59.0 \mathrm{~g} / \mathrm{pot}$ (CD 219RR), with an average value of $53.5 \mathrm{~g} /$ pot. GY of soybean genotypes were significantly affected by P rates (Table 1). At low P level, the highest GY was $17.4 \mathrm{~g} /$ pot (FPS Solar IPRO) and the lowest GY value was $6.0 \mathrm{~g} /$ pot (DM 2302RR), with an average of $11.2 \mathrm{~g} / \mathrm{pot}$, while at $150 \mathrm{mg} \mathrm{P}$ $\mathrm{kg}^{-1}$, the highest GY was $23.8 \mathrm{~g} /$ pot (FPS Solar IPRO) and the lowest was $13.8 \mathrm{~g} /$ pot (TMG 7161RR), with an average value of $20.0 \mathrm{~g} /$ pot, which represents an average increase of $78.6 \%$ with $\mathrm{P}$ application, regardless of the cultivar, compared to the control group. The increase observed in SDW and GY after P addition, regardless of the cultivar, is similar to the findings obtained by Macedo (1985), Moreira and Malavolta (2001), and Fageria et al. (2010). Fageria et al. (2010) reported that besides the genetic factors described by Fageria and Moreira (2010) and Gonçalves and Lynch (2014), such as greater amount of root hairs that increase nutrient uptake efficiency, the response of the plants to $\mathrm{P}$ addition to nonweathered soils is mostly associated to the high $\mathrm{P}$ fixation and immobilization capacity in clays and hence the low $\mathrm{P}$ availability to the crops.

NPP was only affected by soybean genotypes and ranged from 18 (BRS 378RR) to 63 (FPS Solar IPRO), with an average value of 36 when no $\mathrm{P}$ was added, while for dose $150 \mathrm{mg} \mathrm{P} \mathrm{kg}{ }^{-1}, \mathrm{NPP}$ ranged from 26 (BRS 378RR) to 54 (FPS Solar IPRO), and average of 42 (Table 1). Absence of genotype $\times \mathrm{P}$ rates interaction for NPP indicates that this variable is only related to genetic factors, not affected by soil and climatic factors (Fageria et al. 2010), in contrast with GHI that varied significantly from 0.20 (DM 2302RR) to 0.39 (CD 219RR) in the control treatment $\left(\mathrm{P}_{0}\right)$, and after $150 \mathrm{mg} \mathrm{P} \mathrm{kg}{ }^{-1}$ application, from 0.32 (CD 219RR) to 0.41 (FPS Solar IPRO). As reported by Fageria et al. (2010) in common bean plant (Phaseolus vulgaris L.), considering the mean values of the genotypes, GHI increased $32 \%$ after $\mathrm{P}$ addition. Figure 1 shows the significant differences observed in growth, NPP and GY in genotype $7161 \mathrm{RR}$ without $\left(\mathrm{P}_{0}\right)$ and with addition of $\left(\mathrm{P}_{150}\right)$ in

Table 1. Shoot dry weight, grain yield, number of pods, grain harvest index (GHI), and relative yield (RY) of 13 soybean genotypes.

\begin{tabular}{|c|c|c|c|c|c|c|c|c|c|}
\hline \multirow[b]{3}{*}{ Genotypes } & \multicolumn{2}{|c|}{ Shoot dry weight } & \multicolumn{2}{|c|}{ Grain yield } & \multicolumn{2}{|c|}{ Number of pods } & & & \multirow[b]{3}{*}{ RY } \\
\hline & \multirow{2}{*}{$\begin{array}{c}P_{0} \\
\text { (g/pot) }\end{array}$} & \multirow{2}{*}{$\begin{array}{c}P_{150} \\
\text { (g/pot) }\end{array}$} & \multirow{2}{*}{$\begin{array}{c}P_{0} \\
\text { (g/pot) }\end{array}$} & \multirow{2}{*}{$\begin{array}{c}P_{150} \\
\text { (g/pot) }\end{array}$} & \multirow{2}{*}{$\begin{array}{c}P_{0} \\
\text { (n/pot) }\end{array}$} & \multirow{2}{*}{$\begin{array}{c}P_{150} \\
\text { (n/pot) }\end{array}$} & \multicolumn{2}{|c|}{$\mathrm{GHI}$} & \\
\hline & & & & & & & $P_{0}$ & $P_{150}$ & \\
\hline BMX Apolo RR & $34.4 b$ & $51.3 b$ & $8.6 \mathrm{~b}$ & $19.7 b$ & $27 b$ & $37 a$ & $0.25 c$ & $0.37 \mathrm{~b}$ & $45.1 \mathrm{~b}$ \\
\hline BMX Potência RR & $43.2 \mathrm{a}$ & $58.0 \mathrm{a}$ & $11.9 a$ & $23.2 \mathrm{a}$ & $39 a$ & $40 a$ & $0.28 b$ & $0.39 a$ & $51.5 b$ \\
\hline BRS 360RR & $43.0 \mathrm{a}$ & $54.5 a$ & $10.9 a$ & $20.2 a$ & $37 a$ & $37 a$ & $0.25 c$ & $0.37 b$ & $53.9 b$ \\
\hline BRS 378RR & $33.0 \mathrm{~b}$ & $49.5 b$ & $9.4 b$ & $17.5 b$ & $18 b$ & $26 b$ & $0.30 \mathrm{~b}$ & $0.35 b$ & $53.9 b$ \\
\hline CD 219RR & $30.2 b$ & $59.0 \mathrm{a}$ & 11.3a & $18.5 b$ & $30 \mathrm{~b}$ & $51 \mathrm{a}$ & $0.39 a$ & $0.32 b$ & $60.8 b$ \\
\hline DM 2302RR & $30.8 \mathrm{~b}$ & $50.6 b$ & $6.0 \mathrm{~b}$ & $20.8 a$ & $25 b$ & $48 a$ & $0.20 c$ & $0.42 a$ & $28.7 c$ \\
\hline M 6210 IPRO & $46.6 a$ & $53.9 a$ & $14.0 \mathrm{a}$ & $21.5 a$ & $45 a$ & $40 a$ & $0.30 \mathrm{~b}$ & $0.40 \mathrm{a}$ & $65.0 \mathrm{a}$ \\
\hline NA 6262RR & $45.7 a$ & $55.4 a$ & $13.3 a$ & $20.7 a$ & $45 a$ & $46 a$ & $0.29 b$ & $0.37 b$ & $64.5 a$ \\
\hline FPS Solar IPRO & $50.7 a$ & $58.8 \mathrm{a}$ & $17.4 a$ & $23.8 a$ & $63 a$ & $54 a$ & $0.34 a$ & $0.41 a$ & $73.1 \mathrm{a}$ \\
\hline TMG 1066RR & $38.8 \mathrm{a}$ & $50.4 b$ & $11.9 a$ & $18.2 \mathrm{~b}$ & $23 b$ & $46 a$ & $0.31 b$ & $0.36 \mathrm{~b}$ & $65.7 a$ \\
\hline TMG 7161RR & $26.4 b$ & $42.1 b$ & $5.9 b$ & $13.8 \mathrm{c}$ & $23 b$ & $31 b$ & $0.23 c$ & $0.33 b$ & $42.6 b$ \\
\hline Vmax RR & $48.4 a$ & $56.9 a$ & $14.4 a$ & $21.3 a$ & $52 a$ & $46 a$ & $0.30 \mathrm{~b}$ & $0.38 a$ & $67.7 a$ \\
\hline Vtop RR & $45.2 \mathrm{a}$ & $55.5 a$ & $10.7 a$ & $22.0 a$ & $37 a$ & $43 a$ & $0.24 c$ & $0.39 a$ & $48.7 \mathrm{~b}$ \\
\hline Mean & 39.7B & $53.5 \mathrm{~A}$ & $11.2 \mathrm{~B}$ & $20.0 \mathrm{~A}$ & $36 \mathrm{~A}$ & $42 \mathrm{~A}$ & $0.28 \mathrm{~B}$ & $0.37 \mathrm{~A}$ & 55.5 \\
\hline \multicolumn{10}{|l|}{ F Test } \\
\hline Genotype (G) & $8.81^{*}$ & & $9.64^{*}$ & & $4.10^{*}$ & & $5.62^{*}$ & & $6.89^{*}$ \\
\hline$P$ rates $(R)$ & $161.64^{*}$ & & $333.41^{*}$ & & $0.66^{\mathrm{NS}}$ & & $79.34^{*}$ & & - \\
\hline$G \times R$ & $2.32^{*}$ & & $2.06^{*}$ & & $1.97^{\mathrm{NS}}$ & & $2.88^{*}$ & & - \\
\hline CV (\%) & 10.27 & & 13.66 & & 28.55 & & 4.12 & & 9.44 \\
\hline
\end{tabular}

${ }^{*},{ }^{N S}$ Significant at $5 \%$ probability and not significant, respectively. CV - coefficient of variation. Means followed by the lowercase similar letters in the same column and in uppercase in same line within the same variables are not significantly different at $p \leq 0.05$ by Scott Knott test. Low $\left(P_{0}\right)-0 \mathrm{mg} \mathrm{P} \mathrm{kg}{ }^{-1}$. High $\left(P_{150}\right)-150 \mathrm{mg} \mathrm{P} \mathrm{kg}^{-1}$. 


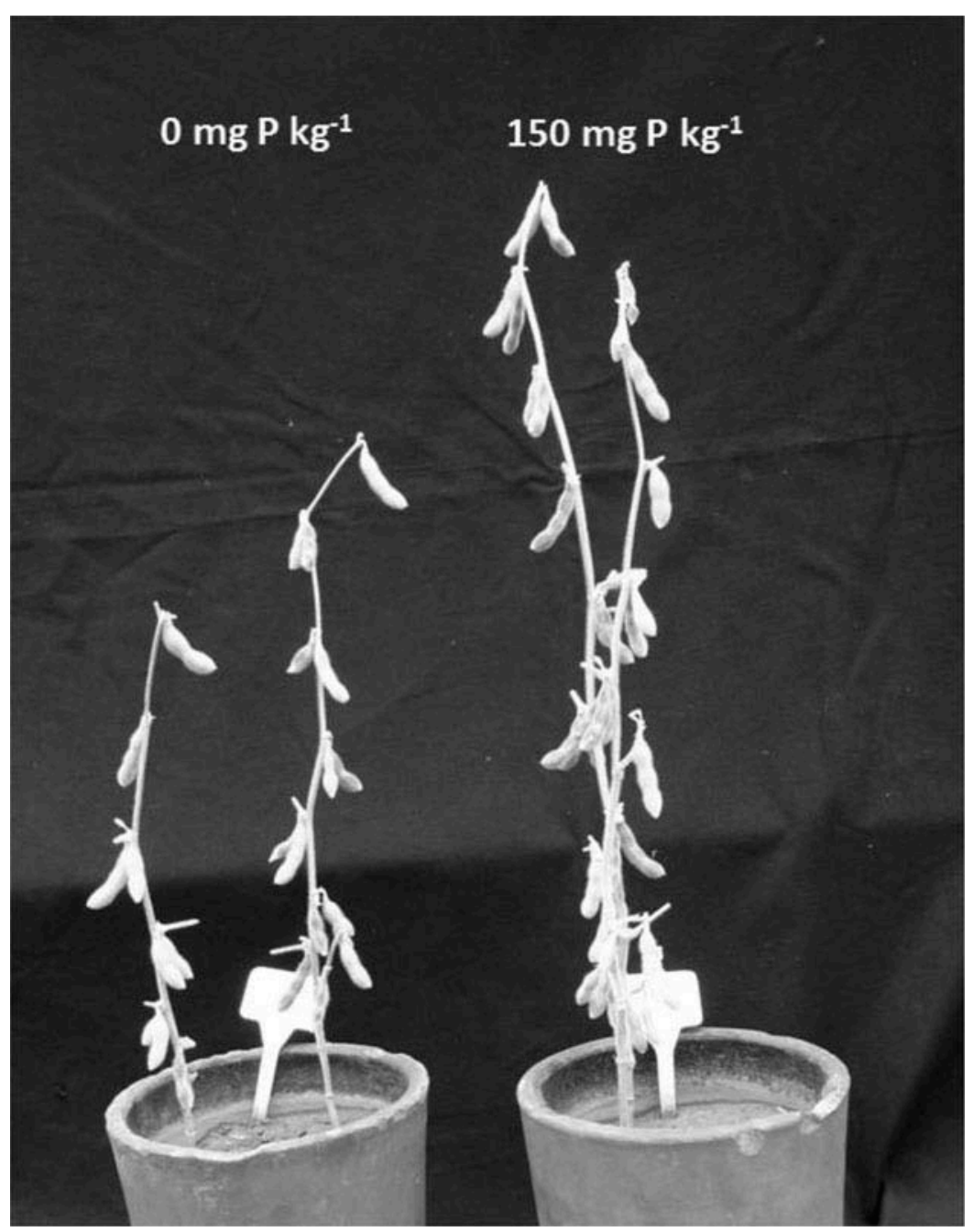

Figure 1. Number of pods (NPP), growth and grain yield of genotype TMG 7161RR at low $\left(0 \mathrm{mg} \mathrm{kg}^{-1}\right)$ and high $\left(150 \mathrm{mg} \mathrm{kg}{ }^{-1}\right) \mathrm{P}$ rates.

the soil. Growth responses, NPP and GY in leguminous plants after P addition to soils with low natural fertility were reported by Nogueira, Bataglia, and Mascarenhas (1977), Aulakh et al. (2003), and Fageria et al. (2013).

Phosphorus use efficiency (Figure 2) indicated that genotypes BMX Apolo RR, BRS 360RR, BRS 378RR, CD 219RR, DM 2302RR, TMG 7161RR, and Vtop RR were included in the group classified as non-efficient and responsive (NER), and demonstrates that their yield is severely affected by unavailability of $\mathrm{P}$. On the other hand, these genotypes are highly responsive when $\mathrm{P}$ was added in the soil. In turn, genotypes BMX Potencia RR, Vmax RR, FPS Solar IPRO, NA 6262RR, TMG 1066RR, and M6210 IPRO were included in the efficient and responsive group (ER). This genotype group has a higher yield than average when no $\mathrm{P}$ is added to the soil, and their yield increases significantly in soils with higher available $\mathrm{P}$ levels or when $\mathrm{P}$ is added to the soil. It should be stressed that Fageria and Baligar (1993) and Fageria, Barbosa Filho, and Moreira (2008) reported that this method is among the most efficient in the classification of species and/or genotypes regarding nutrients use efficiency. 


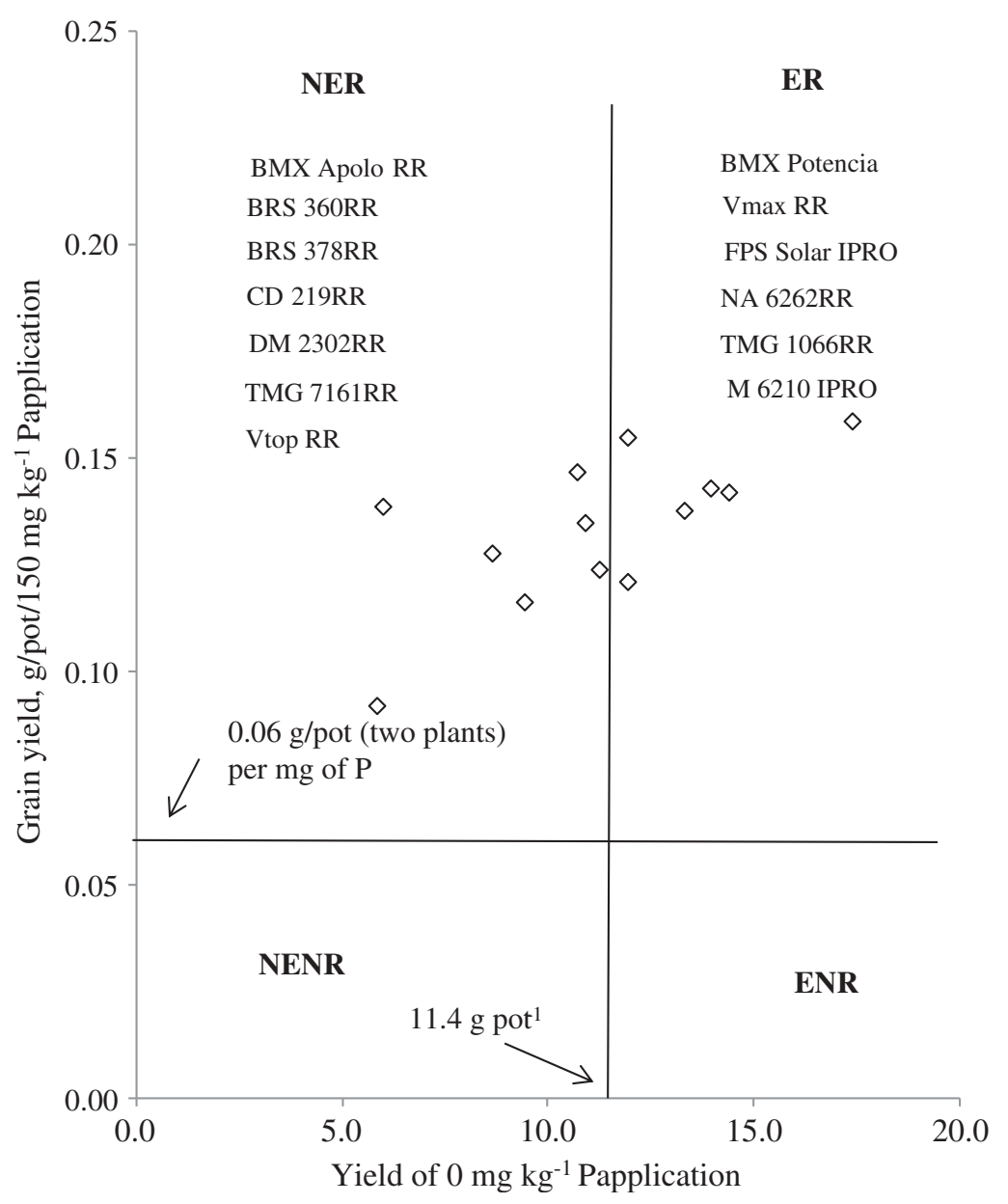

Figure 2. Classification of 13 soybeans genotypes for P-use efficiency. non-efficient and responsive (NER), efficient and responsive (ER), efficient and non-responsive (ENR), and non-efficient and non-responsive (NENR).

\section{Soil chemical properties}

Phosphorus fertilization increased available $\mathrm{P}$ concentration in the soil, with a significant difference between genotypes only for $150 \mathrm{mg} \mathrm{P} \mathrm{kg}^{-1}$ (Table 2). There was a difference (variation) of $122.9 \%$, between genotype NA $6262 \mathrm{RR}$, with the lowest rate $\left(42.8 \mathrm{mg} \mathrm{P} \mathrm{kg}^{-1}\right)$ and TMG 1066RR, with the highest $\mathrm{P}$ rate $\left(95.4 \mathrm{mg} \mathrm{P} \mathrm{kg}{ }^{-1}\right)$ and the average was $72.1 \mathrm{mg} \mathrm{P} \mathrm{kg}{ }^{-1}$. The positive relationship between genotypes regarding $150 \mathrm{mg} \mathrm{P} \mathrm{kg}^{-1} \mathrm{P}(x) \times \mathrm{PG}(\hat{y})$, expressed in equation $\hat{y}=23.564+0.049 x, r=0.36, p \leq 0.05$, shows that plants with higher available $\mathrm{P}$ use in the soil had higher GY, that is, after $\mathrm{P}$ addition during planting, genotypes with lower $\mathrm{P}$ concentration in the soil at the end of the cycle have higher grain yield. In a study with common bean plant, Fageria et al. (2010) found that P is one of the most limiting nutrients for crop yield potential.

The available $\mathrm{S}_{-} \mathrm{SO}_{4}{ }^{2-}, \mathrm{B}, \mathrm{Cu}, \mathrm{Mn}$, and $\mathrm{Zn}$ ranged from $4.2-$ to $7.4-\mathrm{mg} \mathrm{kg}^{-1}, 0.2-$ to $0.3-\mathrm{mg}$ $\mathrm{kg}^{-1}, 0.6$ - to $1.3-\mathrm{mg} \mathrm{kg}^{-1}, 2.8$ - to $5.9-\mathrm{mg} \mathrm{kg}^{-1}$, and 2.4 - to $6.4-\mathrm{mg} \mathrm{kg}^{-1}$, respectively, and varied only among the genotypes, indicating the absence of inhibitory effects or antagonisms in the uptake of these nutrients after $\mathrm{P}$ addition described by Loué (1993) and Malavolta, Vitti, and Oliveira (1997). $\mathrm{pH}, \mathrm{K}^{+}, \mathrm{Ca}^{2+}, \mathrm{Mg}^{2+}, \mathrm{H}^{+}+\mathrm{Al}^{3+}$, and CEC values were not affected by 


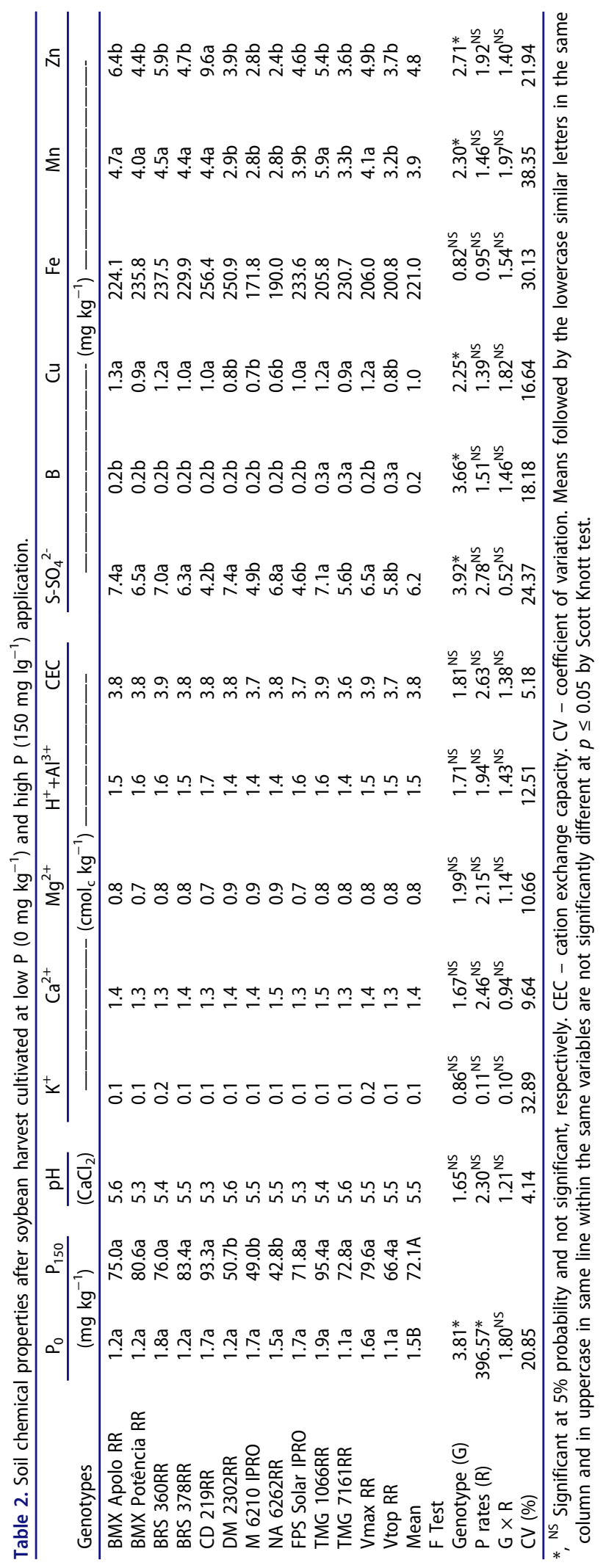


genotypes and $\mathrm{P}$ rates (Table 2). Considering the mean values of genotypes and the two $\mathrm{P}$ levels, after soybean harvest, soil $\mathrm{pH}$ ranged between 5.5 and 6.0 (indicating low acidity) and $\mathrm{K}^{+}, \mathrm{H}^{+}+\mathrm{Al}^{3+}, \mathrm{B}$, and $\mathrm{Mn}$ concentration had low values; exchangeable $\mathrm{Ca}^{2+}$ and $\mathrm{Mg}^{2+}$ were in the average, and $\mathrm{S}_{-} \mathrm{SO}_{4}{ }^{2-}, \mathrm{Fe}$, and $\mathrm{Zn}$ concentration showed high values, according to interpretation class for soil fertility recommended by Alvarez Venegas et al. (1999) for nonweathered tropical soils.

\section{Physiological properties}

Intecellular carbon dioxide concentration $(\mathrm{Ci})$ and Trmmol showed significant genotypes $\times \mathrm{P}$ rates interaction (Table 3), demonstrating that soybean genotypes responded differently to each $\mathrm{P}$ level in the soil for these two variables. Among the genotypes, $\mathrm{Ci}$ and Trmmol ranged from $197.00 \mu \mathrm{mol}$ $\mathrm{CO}_{2} \mathrm{~mol}^{-1}$ (TMG 7161RR) to $288.72 \mu \mathrm{mol} \mathrm{CO} \mathrm{mol}^{-1}$ (DM 2302RR) and from $2.04 \mathrm{mmol} \mathrm{H}_{2} \mathrm{O}$ $\mathrm{m}^{-2} \mathrm{~s}^{-1}$ (TMG 7161RR) to $3.92 \mathrm{mmol} \mathrm{H}_{2} \mathrm{O} \mathrm{m}^{-2} \mathrm{~s}^{-1}$ (Vtop RR) for low $\mathrm{P}$ rate $\left(\mathrm{P}_{0}\right)$ and from 255.92 $\mu \mathrm{mol} \mathrm{CO} \mathrm{mol}^{-1}$ (NA 6262RR) to $313.52 \mu \mathrm{mol} \mathrm{CO} \mathrm{mol}^{-1}$ (BRS 360RR) and $3.05 \mathrm{mmol} \mathrm{H}_{2} \mathrm{O} \mathrm{m}^{-2} \mathrm{~s}^{-1}$ (DM 2302RR) to $4.39 \mathrm{mmol} \mathrm{H}_{2} \mathrm{O} \mathrm{m}^{-2} \mathrm{~s}^{-1}$ (BRS 378RR) to the high $\mathrm{P}$ rate $\left(\mathrm{P}_{150}\right)$. For $A$, $g_{s}$, and chlorophyll content, there was increase of $23.9 \%, 64.3 \%$, and $4.7 \%$ in the average of genotypes with $150 \mathrm{mg} \mathrm{P} \mathrm{kg}{ }^{-1}$. Also, there was a positive relationship of $A(x)$ with GY $(\hat{y}=0.0916+0.996 x, r=0.51$, $p \leq 0.05$ ), and agreement with the findings of Kondracka and Rychter (1997), according to which plants with $\mathrm{P}$ deficiency have reduced carbon assimilation capacity, with negative impact on GY. However, this is not a rule, depending on the extent of nutrient deficiency and on metabolic capacity to respond to low $\mathrm{P}$ supply.

The genotypes responded differently to low $\mathrm{P}$ rate for all the physiological components investigated, which was not observed after addition of $150 \mathrm{mg} \mathrm{P} \mathrm{kg}$, without significant difference (Table 3). Regarding component $A$, genotypes BRS 360RR, CD 219RR, M 6210 IPRO, TMG 1066RR, and TMG 7161RR were the most affected by unavailability of $\mathrm{P}$, obtaining the lowest

Table 3. Photosynthesis rate $(A)$, intercellular $\mathrm{CO}_{2}$ concentration $(\mathrm{Ci})$, stomatal conductance $\left(g_{s}\right)$, transpiration rate $(\mathrm{Trmmol})$, and chlorophyll level of 13 soybean genotypes at two $P$ levels.

\begin{tabular}{|c|c|c|c|c|c|c|c|c|c|c|}
\hline \multirow[b]{3}{*}{ Genotypes } & \multicolumn{2}{|c|}{$\begin{array}{l}\text { Photosynthesis } \\
\text { rate }\end{array}$} & \multicolumn{2}{|c|}{$\begin{array}{l}\text { Intercellular } \mathrm{CO}_{2} \\
\text { conc. }\end{array}$} & \multicolumn{2}{|c|}{$\begin{array}{c}\text { Stomatal } \\
\text { conductance }\end{array}$} & \multicolumn{2}{|c|}{ Transpiration rate } & \multicolumn{2}{|c|}{ Chlorophyll } \\
\hline & $P_{0}$ & $P_{150}$ & $P_{0}$ & $P_{150}$ & $P_{0}$ & $P_{150}$ & $P_{0}$ & $P_{150}$ & $P_{0}$ & $P_{150}$ \\
\hline & \multicolumn{2}{|c|}{$\left(\mu \mathrm{mol} \mathrm{CO}_{2} \mathrm{~m}^{-2} \mathrm{~s}^{-1}\right)$} & \multicolumn{2}{|c|}{$\left(\mu \mathrm{mol} \mathrm{CO} \mathrm{mol}^{-1}\right)$} & \multicolumn{2}{|c|}{$\left(\mathrm{mol} \mathrm{H}_{2} \mathrm{O} \mathrm{m}^{-2} \mathrm{~s}^{-1}\right)$} & \multicolumn{2}{|c|}{$\begin{array}{c}(\mathrm{mmol} \\
\left.\mathrm{H}_{2} \mathrm{O} \mathrm{m}^{-2} \mathrm{~s}^{-1}\right)\end{array}$} & \multicolumn{2}{|c|}{$\left(\mathrm{mg} \mathrm{m}^{-2}\right)$} \\
\hline BMX Apolo RR & $16.65 a$ & $17.75 a$ & $267.00 a$ & $267.94 b$ & $0.41 a$ & $0.42 a$ & $4.11 a$ & $3.30 a$ & $267.92 a$ & $265.58 a$ \\
\hline BMX Potência RR & $14.76 a$ & $16.51 a$ & $258.12 a$ & $296.12 a$ & $0.26 \mathrm{~b}$ & $0.46 a$ & $3.07 \mathrm{~b}$ & $3.76 a$ & $234.07 a$ & $260.09 a$ \\
\hline BRS 360RR & $11.31 b$ & $16.86 a$ & $286.88 a$ & $313.52 a$ & $0.26 \mathrm{~b}$ & $0.56 a$ & $2.89 \mathrm{~b}$ & $3.26 a$ & $254.15 a$ & $245.88 a$ \\
\hline BRS 378RR & $14.70 a$ & $19.33 a$ & $254.50 a$ & $275.27 b$ & $0.29 \mathrm{~b}$ & $0.53 a$ & $3.21 \mathrm{a}$ & $4.39 a$ & $245.44 a$ & $266.84 a$ \\
\hline CD 219RR & $11.28 \mathrm{~b}$ & $13.92 \mathrm{a}$ & $279.84 a$ & $283.87 b$ & $0.20 \mathrm{~b}$ & $0.37 a$ & $2.90 \mathrm{a}$ & $3.79 a$ & $223.27 b$ & $247.14 a$ \\
\hline DM 2302RR & $16.01 \mathrm{a}$ & $14.98 a$ & $288.72 a$ & $274.28 b$ & $0.37 a$ & $0.32 \mathrm{a}$ & $3.14 a$ & $3.05 a$ & $245.94 a$ & $230.01 a$ \\
\hline M 6210 IPRO & $10.86 \mathrm{~b}$ & $16.96 a$ & $264.66 a$ & $277.46 b$ & $0.17 \mathrm{~b}$ & $0.44 a$ & $2.09 c$ & $3.93 a$ & $227.88 b$ & $250.55 a$ \\
\hline NA 6262RR & $17.73 a$ & $18.43 a$ & $263.96 a$ & $255.92 b$ & $0.41 a$ & $0.43 a$ & $3.91 \mathrm{a}$ & $3.87 a$ & $269.69 a$ & $261.98 a$ \\
\hline FPS Solar IPRO & $14.16 a$ & $16.58 a$ & $262.52 a$ & $300.29 a$ & $0.20 \mathrm{~b}$ & $0.50 a$ & $2.29 c$ & $3.81 a$ & $191.07 b$ & $219.49 a$ \\
\hline TMG 1066RR & $11.62 b$ & $18.29 a$ & $284.65 a$ & $273.57 \mathrm{~b}$ & $0.27 b$ & $0.47 a$ & $2.84 a$ & $3.92 \mathrm{a}$ & $239.19 a$ & $253.46 a$ \\
\hline TMG 7161RR & $9.91 b$ & $17.37 a$ & 197.00b & $274.91 b$ & $0.10 \mathrm{~b}$ & $0.43 a$ & $2.04 c$ & $3.84 a$ & $266.59 a$ & $279.60 a$ \\
\hline Vmax RR & $14.41 \mathrm{a}$ & $18.30 a$ & $259.67 a$ & $268.67 b$ & $0.29 b$ & $0.52 \mathrm{a}$ & $3.58 \mathrm{a}$ & $4.28 \mathrm{a}$ & $245.05 a$ & $257.75 a$ \\
\hline Vtop RR & $17.87 \mathrm{a}$ & $19.17 a$ & $272.04 a$ & $276.87 b$ & $0.41 a$ & $0.54 a$ & $3.92 \mathrm{a}$ & $4.19 a$ & $240.58 a$ & $260.09 a$ \\
\hline Mean & $13.94 \mathrm{~B}$ & $17.27 \mathrm{~A}$ & $264.58 \mathrm{~A}$ & $279.90 B$ & $0.28 \mathrm{~B}$ & $0.46 \mathrm{~A}$ & $3.08 \mathrm{~B}$ & $3.80 \mathrm{~A}$ & $242.37 B$ & $253.73 \mathrm{~A}$ \\
\hline \multicolumn{11}{|l|}{ F Test } \\
\hline Genotype (G) & $3.82^{*}$ & & $3.88^{*}$ & & $1.60^{\mathrm{NS}}$ & & $2.60^{*}$ & & $3.54^{*}$ & \\
\hline$P$ rates $(R)$ & $20.51^{*}$ & & $12.99^{*}$ & & $47.80^{*}$ & & $28.26^{*}$ & & $5.00^{*}$ & \\
\hline$G \times R$ & $0.97^{\mathrm{NS}}$ & & $2.74^{*}$ & & $1.65^{\mathrm{NS}}$ & & $2.54^{*}$ & & $0.66^{\mathrm{NS}}$ & \\
\hline CV (\%) & 20.70 & & 6.89 & & 30.99 & & 17.46 & & 9.04 & \\
\hline
\end{tabular}

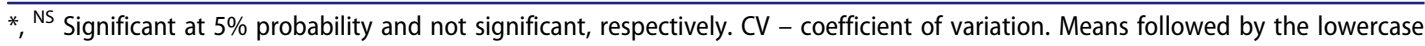
similar letters in the same column and in uppercase in same line within the same variables are not significantly different at $p \leq 0.05$ by Scott Knott test. Low $\left(P_{0}\right)-0 \mathrm{mg} \mathrm{P} \mathrm{kg}^{-1}$. High $\left(\mathrm{P}_{150}\right)-150 \mathrm{mg} \mathrm{P} \mathrm{kg}^{-1}$. 
values, while considering component chlorophyll content, DM 2302RR, M 6210 IPRO, and FPS Solar IPRO were the genotypes showing the lowest values. That is, depending on available P levels in the soil, each genotype and/or species may show different characteristics regarding light interception and photoassimilates use. Thus, corroborating such findings, efficient $\mathrm{P}$ use during photosynthesis is a potentially important factor for crop growth and yield. However, some plants may develop strategies to deal with low availability of $\mathrm{P}$, maintaining an adequate internal balance of the nutrient (Zhang et al. 2016).

\section{Nutrient concentration in the leaves and grains}

Only $\mathrm{P}$ concentration in the leaves and $\mathrm{K}$ concentration in the grains were affected by genotypes $(G)$, rates $(R)$, and interaction $G \times R$, while leaf and grain $N, C a, M g$, and $S$ concentrations differed significantly only among the genotypes and $\mathrm{Ca}, \mathrm{Mg}$, and $\mathrm{S}$ in the leaves also differed significantly for $\mathrm{P}$ rates (Tables 4 and 5). When no $\mathrm{P}$ was added, leaf $\mathrm{P}$ concentration varied $36.4 \%$ from $1.1 \mathrm{~g} \mathrm{~kg}^{-1}$ (CD 219RR) to $1.5 \mathrm{~g} \mathrm{~kg}^{-1}$ (TMG 7161RR) and in average value of $1.4 \mathrm{mg} \mathrm{kg}^{-1}$, while with addition of $150 \mathrm{mg} \mathrm{P} \mathrm{kg}{ }^{-1}$, leaf $\mathrm{P}$ concentration varied $15.1 \%$ from $3.3 \mathrm{~g} \mathrm{~kg}^{-1}$ (BRS 360RR) to $3.8 \mathrm{~g} \mathrm{~kg}^{-1}$ (Vmax RR), and in average value of $3.6 \mathrm{mg}$ $\mathrm{kg}^{-1}$ (Table 4). Urano et al. (2006) reported that the appropriate leaf $\mathrm{P}$ concentration to obtain high grain yield range from $2.2-$ to $3.7-\mathrm{g} \mathrm{kg}^{-1}$. In the grains (Table 5), P concentration varied 87.2\% from $3.9 \mathrm{~g} \mathrm{~kg}^{-1}$ (FPS Solar IPRO) to $7.3 \mathrm{~g} \mathrm{~kg}^{-1}$ (NA 6262RR) and average value of $5.4 \mathrm{~g}$ $\mathrm{kg}^{-1}$ for the lower $\mathrm{P}$ rate and for the $150 \mathrm{mg} \mathrm{P} \mathrm{kg}$, it varied $34.6 \%$ from $10.4 \mathrm{~g} \mathrm{~kg}^{-1}$ (TMG $7161 \mathrm{RR}$ ) to $20.9 \mathrm{~g} \mathrm{~kg}^{-1}$ (NA 6262RR), and average value of $14.0 \mathrm{~g} \mathrm{~kg}^{-1}$. Baligar, Fageria, and He (2001), Fageria and Moreira (2010), and Gonçalves and Lynch (2014) reported that when the plants are grown under the same soil and climatic conditions, the different soybean genotypes responses to the different $\mathrm{P}$ levels can be explained by the genetic characteristics of the plants, such as morphology of root system and density of adventitious roots, which improve nutrient uptake efficiency.

Considering the mean values of the genotypes, leaf $\mathrm{N}, \mathrm{K}, \mathrm{Ca}, \mathrm{Mg}$, and $\mathrm{S}$ concentrations were within the ranges recommended as suitable by Malavolta, Vitti, and Oliveira (1997) and Urano et al. (2006) for soybean cultivation under tropical and subtropical conditions, and between the low and high $\mathrm{P}$ rates, they ranged from 44.1 - to $44.4-\mathrm{g} \mathrm{N} \mathrm{kg}^{-1}, 20.6$ - to $20.8-\mathrm{g} \mathrm{K} \mathrm{kg}^{-1}, 10.3$ - to $10.6-\mathrm{g} \mathrm{Ca} \mathrm{kg}^{-1}$, 4.3- to 4.5-g Mg kg-1, and 3.1- to 3.2-g S kg ${ }^{-1}$, respectively (Table 4). N, K, Ca, Mg, and S concentration in the grains also did not differ significantly for the two $\mathrm{P}$ rates and ranged from 56.6- to $57.7-\mathrm{g} \mathrm{N} \mathrm{kg}^{-1}, 25.1$ - to $26.0-\mathrm{g} \mathrm{K} \mathrm{kg}^{-1}$, 3.3- to 3.4-g $\mathrm{Ca} \mathrm{kg}^{-1}, 3.4$ - to $3.5-\mathrm{g} \mathrm{Mg} \mathrm{kg}^{-1}$, and 4.6- to 4.7-g S kg-1, respectively. Except for N, nutrients concentration in soybean grains were higher than those obtained by Moreira, Moraes, and Fageria (2015) with the same soil type studied (Ustoxix Quartzipsamment).

\section{Conclusions}

Under tropical and subtropical conditions, unavailability of $\mathrm{P}$ in the soil is one of the main limiting factors of crop yield, and the selection of genotypes more adapted to this soil condition can be a valuable tool in the management of soybean crops. Therefore, among the genotypes tested, BMX Apolo RR, BRS 378RR, DM 2302RR, and TMG 7161RR were the genotypes most sensitive to low P rates in the soil (non-efficient and responsive), while DM 2302RR was the most responsive and had the lowest relative yield $(\mathrm{RY}=28.8 \%)$. $A, g_{s}$, ci, Tmmol, chlorophyll content, and P concentration in the leaves and grains were affected by $\mathrm{P}$ rates and except for $g_{s}$, were also affected by the different soybean genotypes. Leaf macronutrients concentration ranged depending on $\mathrm{P}$ rates, as follows: $\mathrm{N}>\mathrm{K}>\mathrm{Ca}>\mathrm{Mg}>\mathrm{S}>\mathrm{P}$ at low $\mathrm{P}$ rate and $\mathrm{N}>\mathrm{K}>\mathrm{Ca}>\mathrm{Mg}>\mathrm{S}>\mathrm{P}$ at high $\mathrm{P}$ rate, while grain macronutrients concentration was $\mathrm{N}>\mathrm{K}>\mathrm{P}>\mathrm{S}>\mathrm{Mg}>\mathrm{Ca}$ at low and high $\mathrm{P}$ rates. The variability among genotypes intra an inter $\mathrm{P}$ rates demonstrates that genotype selection that does not consider 


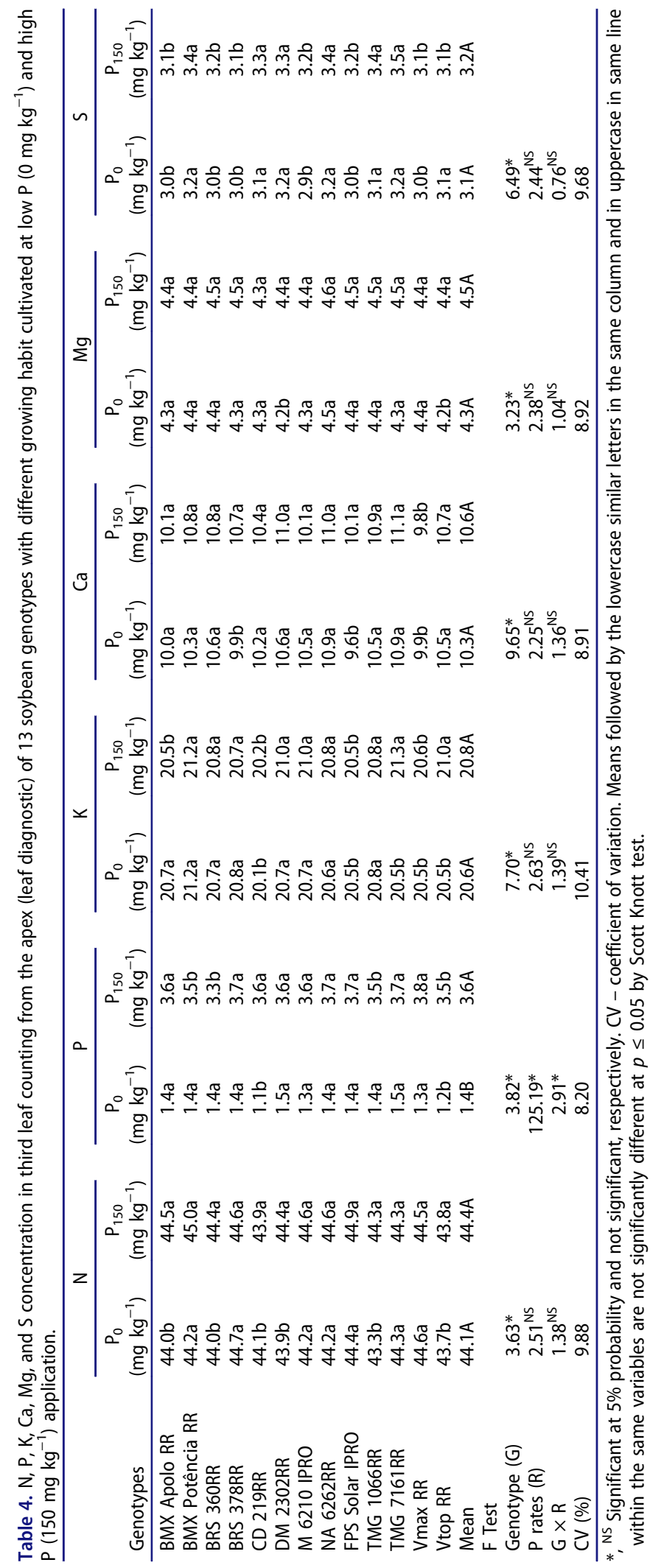




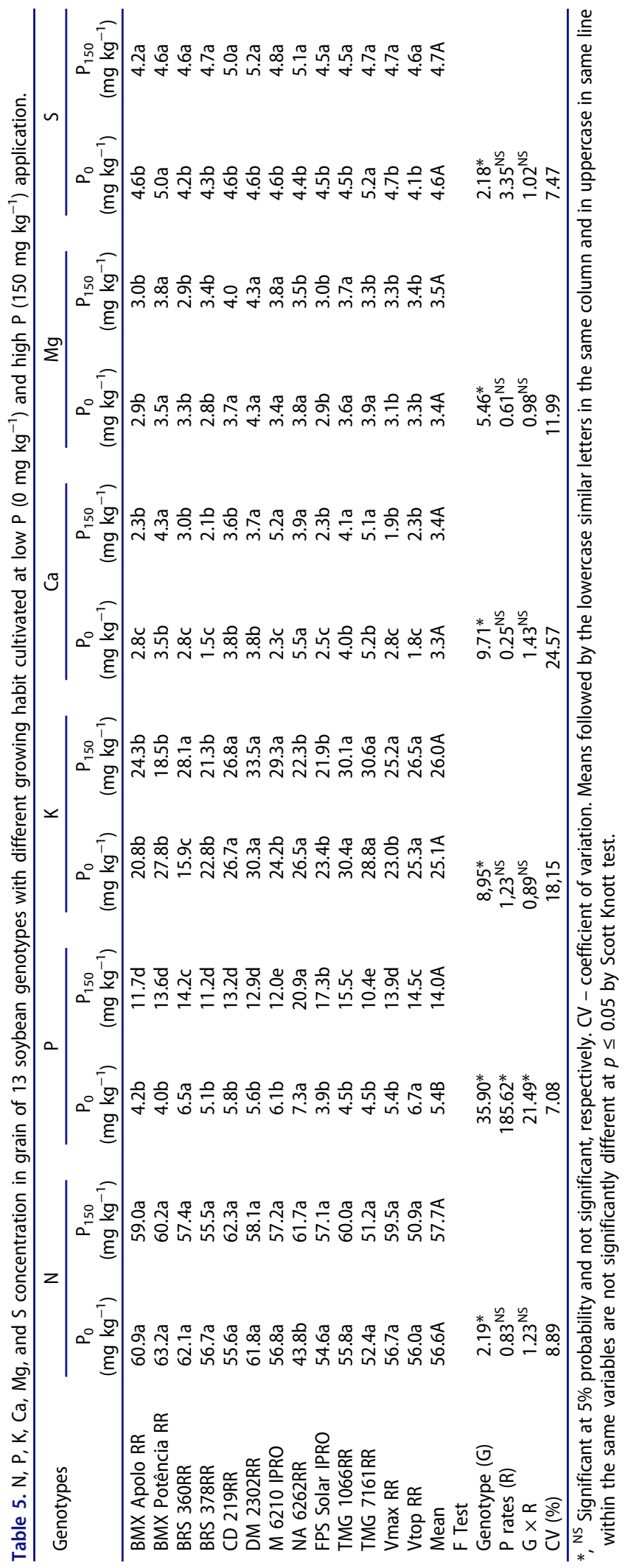


its $\mathrm{P}$ use efficiency and the soil and climate conditions of the planting may have a significant impact on soybean grain yield.

\section{Acknowledgments}

To Laboratory Santa Rita for soil analyses, to UNESP Ilha Solteira for leaf and grain analyses, and to CNPq (National Council for Scientific and Technological Development) for the research productivity fellowship granted to the first author.

\section{References}

Allen, S. E., G. L. Terman, and L. B. Clements. 1976. Greenhouse techniques for soil-plant fertilizer research. Muscle Shoals, USA: Tennessee Valley Authority.

Alvarez Venegas, V. H., R. F. Novais, N. F. Barros, R. B. Cantarutti, and A. S. Lopes. 1999. Interpretation of soil analysis results. In Recommendation for the Use of Lime and Fertilizers in Minas Gerais State, eds. A. C. Ribeiro, P. T. Guimarães, and V. H. A. Venegas, 25-32. Viçosa, Brazil: CFSEMG.

Aulakh, M. S., N. S. Pasricha, and G. S. Bahl. 2003. Phosphorus fertilizer response in an irrigated soybean-wheat production system on a subtropical, semiarid soil. Field Crops Research 80:99-109.

Baligar, V. C., N. K. Fageria, and L. He. 2001. Nutrient use efficiency in plants. Communications in Soil Science and Plant Analysis 32:921-50.

Batten, G. D. 1992. A review of phosphorus efficiency in wheat. Plant and Soil 146:163-68.

Chien, S. H., and R. G. Menon. 1995. Factors affecting the agronomic effectiveness of phosphate rock for direct application. Fertilizer Research 41:227-34.

Cordell, D., J. O. Drangert, and S. White. 2009. The story of phosphorus: Global food security and food for thought. Global Environmental Change 9:292-305.

EMBRAPA (Empresa Brasileira de Pesquisa Agropecuaria). 1997. Manual for methods of soil analysis, 2nd ed. Rio de Janeiro, Brazil: National Research Center for Soils.

Fageria, N. K. 2009. The use of nutrients in crop plants. Boca Raton, FL: CRC Press.

Fageria, N. K., and V. C. Baligar. 1993. Screening crop genotypes for mineral stresses. Proceedings of the Workshop on Adaptation of Plants to Soil Stress (INTSORMIL Publication No. 94-2), 142-59. Lincoln, Neb.: University of Nebraska.

Fageria, N. K., V. C. Baligar, A. Moreira, and L. A. C. Moraes. 2013. Soil phosphorous influence on growth and nutrition of tropical legume cover crops in acidic soil. Communications in Soil Science and Plant Analysis 44:334064.

Fageria, N. K., V. C. Baligar, A. Moreira, and T. A. Portes. 2010. Dry bean genotypes evaluation for growth, yield components and phosphorus use efficiency. Journal of Plant Nutrition 33:2167-81.

Fageria, N. K., M. P. Barbosa Filho, and A. Moreira. 2008. Screening upland rice genotype for manganese-use efficiency. Communications in Soil Science and Plant Analysis 39:2873-82.

Fageria, N. K., and A. Moreira. 2010. The role of mineral nutrition on root growth of crop plants. Advances in Agronomy 110:251-331.

Fehr, W. R., C. E. Caviness, D. T. Burmood, and J. S. Pennington. 1971. Stage of development description for soybeans (Glycine max (L.) Merrill). Crop Science 11:929-31.

Fritschi, F. B., and J. D. Ray. 2007. Soybean leaf nitrogen, chlorophyll content, and chlorophyll a/b ratio. Photosynthetica 45:92-98.

Furtini Neto, A. E., N. F. Barros, M. F. Godoy, and R. F. Novais. 1996. Phosphorus nutritional efficiency of Eucalyptus seedlings. Revista Árvore 20:17-28.

Goedert, W. J., and D. M. G. Sousa. 1986. Preliminar evaluation of the agronomic efficiency on partially acidulated phosphates. Revista Brasileira De Ciência Do Solo 10:75-80.

Gonçalves, S. L., and J. P. Lynch. 2014. Roots of annual plants: Tolerance to environmental stresses, efficiency in absorbing nutrients and methods for selection of genotypes. Londrina, Brazil: Embrapa Soybean.

Kondracka, A., and A. M. Rychter. 1997. The role of Pi recycling processes during photosynthesis in phosphatedeficient bean plants. Journal of Experimental Botany 48:1461-68.

Lápido-Loureiro, F. E., R. Melamed, and J. Figueiredo Neto. 2009. Fertilizantes: Agroindústria e sustentabilidade [Fertilizer: Agribusiness and sustainability]. Rio de Janeiro, Brazil: CETEM.

Loué, A. 1993. Oligoeléments en Agriculture [Micronutrientes in Agriculture]. Antibes, France: SCPA/NATHAN.

Macedo, W. 1985. The effect of sources and levels of phosphorus and lime for forage pasture fertilization in Rio Grande do Sul. Pesquisa Agropecuária Brasileira 20:643-57.

Malavolta, E., G. C. Vitti, and A. A. Oliveira. 1997. Avaliação do Estado Nutricional de Plantas; princípios e aplicações [Evaluation of nutritional status of plants; principles and application]. Piracicaba, Brazil: Potafos. 
McIvor, J. G. 1984. Phosphorus requirements and responses of tropical pasture species native and introduced grasses, and introduced legumes. Australian Journal Experimental Agriculture Animal Husbandry 24:370-78.

Moreira, A., and N. K. Fageria. 2010. Liming influence on soil chemical properties, nutritional status and yield of alfalfa grown in acid soil. Revista Brasileira De Ciência Do Solo 34:1231-39.

Moreira, A., and E. Malavolta. 2001. Sources, rates and extractants of phosphorus on alfalfa and centrosema. Pesquisa Agropecuária Brasileira 36:1519-27.

Moreira, A., L. A. C. Moraes, and N. K. Fageria. 2015. Variability on yield, nutritional status, soil fertility, and potassium-use efficiency by soybean cultivar in acidic soil. Communications in Soil Science and Plant Analysis 46:2490-508.

Nogueira, S. S. S., O. C. Bataglia, and H. A. A. Mascarenhas. 1977. Effects of source and levels of phosphorus on the leaf area and production of soybeans. Bragantia 36:27-29.

Scott, A., and M. Knott. 1974. Cluster-analysis method for grouping means in analysis of variance. Biometrics 30:50712.

Silva, C. M. M. S., and C. M. B. Faria. 1989. Behavior of tropical forage legumes under different fertilization in Petrolina, Pernambuco, Brazil. Pesquisa Agropecuária Brasileira 24:1319-23.

Urano, E. O. M., C. H. Kurihara, S. Maeda, A. C. T. Vitorino, M. C. Gonçalves, and M. E. Marchetti. 2006. Soybean nutritional status evaluation. Pesquisa Agropecuária Brasileira 41:1421-28.

Xie, Y., X. Niu, and J. Niu. 2016. Effect of phosphorus fertilizer on growth, phosphorus uptake, seed yield, yield components, and phosphorus use efficiency of oilseed flax. Agronomy Journal 108:1257-66.

Zhang, K., H. Liu, J. Song, W. Wu, K. Li, and J. Zhang. 2016. Physiological and comparative proteome analyses reveal low-phosphate tolerance and enhanced photosynthesis in a maize mutant owing to reinforced inorganic phosphate recycling. BMC Plant Biology 16:1-15. 